\title{
SCREENING OF SPRING WHEAT VARIETIES RESISTANT TO SOIL POLUTION WITH HEAVY METALS TO CREATE ECOLOGICALLY PURE PRODUCTION
}

\author{
R.A. Alybayeva, A.S. Alenova, V.I. Kruzhaeva and I.M. Salmenova \\ Al-Farabi Kazakh National University, Department of UNESCO chair for Sustainable development, Almaty, \\ Kazakhstan
}

\begin{abstract}
The problem of obtaining safe foodstuff has remained relevant for a very long time. Long period of soil self-purification and the expensiveness of its artificial treatment force mankind to look for new ways to solve problems related to soil pollution with heavy metals. The most perspective direction in this field is the identification of plant facilities, characterized by minimal accumulation of heavy metals. The purpose of our research is to identify wheat germplasm, resistant to heavy metals (zinc, cadmium) primarily in Eastern Kazakhstan, and discover donors for selection for metal resistance and perspective wheat forms, intended to implement into production. The research subject is various genotypes of spring wheat from the collection of Eastern Kazakhstan Agricultural Scientific Research Institute. The experiments were held in condition of modeling environmental pollution on 10-day-old sprouts of different wheat genotypes, grown on nutrient mixture, containing $\mathrm{CaSO}_{4}$ $0.1 \mathrm{~mm}$ and $\mathrm{Cd}$ ions at a concentration of $40 \mathrm{mg} / 1$ (as $\mathrm{CdSO}_{4}$ salt) or $\mathrm{Zn}$ at a concentration of 400 $\mathrm{mg} / \mathrm{l}$ (a salt $\mathrm{ZnSO}_{4}$ ). Since a direct negative impact of heavy metals on plants is displayed in inhibiting of their growth and development (root and sprout growth weakening), indicators of wheat genotypes growth processes were examined during the experiment and Wilkins coefficient was defined. The study revealed sensitive and metal resistant samples. Spring wheat varieties Zaulbinka and Altai turned out to be the most resistant to zinc translocation into the surface organs in the course of experiment among the studied genotypes, and Erythrospermum-606 is the most sensitive type of spring wheat. Spring wheat Altai has shown the biggest root resistance to the effect of zinc. Altai, Nargiz and Glubochanka can be considered the most resistant varieties of spring wheat to translocation of cadmium into the surface organs in terms of experiment, among the studied genotypes, and Erythrospermum-606 is the most sensitive variety of spring wheat. Spring wheat varieties: Nargiz, Ulbinka-25, Altai and Glubochanka have shown the biggest root resistance to the cadmium effect. Studies of membrane permeability for electrolytes in terms of environmental pollution by cadmium and zinc, have led to the conclusion that plant resistance can generally be caused by cell membranes' resistance to the action of the stressor. Membrane permeability for electrolytes in the most resistant wheat variety Altai changed less comparing to a more sensitive variety of spring wheat Erythrospermum-606 during the action of both cadmium and zinc. This fact proves that the overall resistance of plants may be due to stability of cell membrane to the action of the stressor.
\end{abstract}

Keywords: membrane permeability, heavy metals, wheat, growth parameters, accumulation of metals, sensitive and resistant genotypes

\section{BACKGROUND/ OBJECTIVES AND GOALS}

In Kazakhstan, the development of a powerful industry was based on its rich natural resources. However, the industrial centers are the areas of highest contamination by heavy metals [1]. Sound environmental technologies are crucial to address heavy metal pollution. Development and use of plant varieties characterized by minimal accumulation of heavy metals can provide one such environmental solution. 
Plants, grown in contaminated soils, exhibit significant interspecies differences in responses to pollution. The available literature data showed that a significant positive correlation between the concentration of heavy metals in the grain and genotypes, indicating the possibility of breeding varieties with a low potential for accumulation of heavy metals [2].

Characterization of heavy metal accumulation in wheat and identification of germplasm resistance to influence of heavy metals is an important step towards the creation and use of wheat varieties resistant to heavy metal pollutions in agricultural production systems. This requires the study of the gene pool of cultivated plants and the selection of donors that accumulate minimum amount of heavy metals and varieties that are promising for cultivation in areas contaminated with heavy metals

The aim of this study was to identify wheat germplasm resistant to heavy metals (zinc and cadmium), which are important to the Eastern Kazakhstan region and identification of donors for breeding and promising forms destined for agricultural production.

\section{METHODS}

Studies were carried out on various genotypes of spring wheat from the collection of Eastern Kazakhstan Agricultural Scientific Research Institute. The following spring wheat genotypes were examined during the experiment: Altai, Ulbinka-25, Zaulbinka, Lyazzat, Glubochanka, Nargiz, Omskaya18, Samal, Erythrospermum-606, Kutulukskaya.

Plant growth was held in terms of modeling environmental pollution on 10-day-old sprouts of different wheat genotypes, grown on nutrient mixture, which contains $\mathrm{CaSO} 40.1 \mathrm{~mm}$ and $\mathrm{Cd}$ ions at a concentration of $40 \mathrm{mg} / \mathrm{l}\left(\mathrm{CdSO}_{4}\right.$ salt $)$ or $\mathrm{Zn}$ at a concentration of $400 \mathrm{mg} / \mathrm{l}$ (as a $\mathrm{ZnSO}_{4}$ salt). The plants were grown for 10 days in water culture with t$22^{\circ} \mathrm{C}$ during the day and $18^{\circ} \mathrm{C}$ at night, with a 14 -hour photoperiod, light intensity - 5 thousand $1 x$, humidity $-65 \%$.

The measurement of biometric indicators was carried out according to common methods. The plants were dissected to an over-ground part and roots. Roots and surface organs length were measured. In order to determine the plants' dry biomass, they were put in a drying cabinet and dried at $\mathrm{t}-105^{\circ} \mathrm{C}$ till constant weight, cooled down to room temperature and weighed.

The tolerance index or Wilkins coefficient were calculated using the formula: $\mathrm{I}_{\mathrm{t}}=\mathrm{I}_{\mathrm{me}} / \mathrm{I}_{\mathrm{c}}$, where $\mathrm{I}_{\mathrm{me}}$ growth of the roots on the solution of the tested metal, $I_{c}$ - growth of the roots on the solution without metal [3].

The testing of contrasting by stability spring wheat genotypes for the permeability of cell membranes was conducted in laboratory conditions. To research the permeability of wheat cell membranes, identified during experiments on study of growth parameters wheat varieties contrasting by resistance were used, resistant - Altai and sensitive - Erythrospermum-606.

Membrane permeability determination for electrolytes was conducted according to Dexter conduct metric method [4]. Modified Dexter method was used to determine the release of electrolytes from plants leaves tissues, exposed to the stress effect. A weighed sample of $500 \mathrm{mg}$ leaves was immersed into $50 \mathrm{ml}$ water with the known conductivity for $60-180$ min. The exudate was drained out and electro conductivity was measured by conductivity meter at the end of the exposure. After the counting the exudate was poured into the same cup with the sample and was boiled up and its electro conductivity was re-measured. Calculation formula: \% electrolytes elution $=(\mathrm{a}: \mathrm{b}) \mathrm{x} 100$, where $\mathrm{a}-$ is the conductivity of dead tissues, $\mathrm{b}$ - is the conductivity of living specimens.

\section{RESULTS}

Our study of cadmium and zinc effect on growth parameters of wheat sprouts in the laboratory conditions showed that the ions of both cadmium and zinc inhibit plant growth.

The research on wheat varieties from the Eastern Kazakhstan Agricultural Scientific Research Institute collection showed that by the growth of surface organs at a high concentration of cadmium, genotypes can be arranged as follows: Altai > Nargiz > Glubochanka > Ulbinka-25 > Samal > Omskaya-18 > 
Kutulukskaya > Zaulbinka > Lyazzat > Erythrospermum-606 (Figure 1).

Regarding zinc, the results are the following: by the growth of surface organs at a high zinc concentration, genotypes can be arranged as follows: Zaulbinka > Altai > Ulbinka-25> Lyazzat > Glubochanka > Kutulukskaya > Nargiz > Omskaya-18 > Samal > Erythrospermum-606 (Figure 2).

Based on the received data, we see that in both cases, by the growth of surface sprouts, Altai is the wheat variety least exposed to effect of zinc and cadmium ions, while surface sprouts of variety Erythrospermum-606 acutely react on the presence of heavy metal ions.

Samal, Omskaya-18, Kutulukskaya and Zaulbinka wheat varieties showed average resistance to the cadmium effect according to the growth parameters of surface organs. When introducing zinc to the cultivation medium, growth of surface organs of varieties Lyazzat, Glubochanka, Kutulukskaya, Nargiz, Omskaya-18 is inhibited at the average degree, comparing to other varieties, which is the indicator of average metal endurance.

By the root growth, at introducing cadmium to the nutrition medium, genotypes can be arranged the following way: Nargiz > Ulbinka-25> Altai > Glubochanka > Omskaya-18 > Zaulbinka > Lyazzat $>$ Kutulukskaya > Erythrospermum-606 > Samal (Figure 3).

Altai, Ulbinka-25 and Nargiz have the most resistant to cadmium root system. Root growth of varieties Nargiz, Ulbinka-25 and Altai is inhibited in much less degree comparing to other genotypes at a high cadmium concentration in cultivation medium. Varieties Glubochanka, Omskaya-18, Zaulbinka and Lyazzat have an average root resistance level. Plant roots of varieties Erythrospermum-606 and Samal turned to be the most non-resistant to the adverse cadmium effect (Figure 3). When studying the impact of zinc on growth parameters of varieties from the Eastern Kazakhstan Agricultural Scientific Research Institute collection, it was shown that by the root growth at a high zinc concentration genotypes can be arranged as follows: Altai > Ulbinka-25 > Zaulbinka > Lyazzat > Glubochanka > Nargiz >
Omskaya-18 > Samal > Erythrospermum-606 > Kutulukskaya (Figure 4).

Varieties Altai, Ulbinka-25 and Zaulbinka have the most zinc resistant root system. Lyazzat, Glubochanka and Nargiz have an average roots resistance level. Altai, Ulbinka-25 and Zaulbinka varieties' root growth is inhibited less comparing to other genotypes that were introduced to zinc growth medium. Varieties Omskaya-18, Samal and Erythrospermum-606 are less resistant to the adverse effect of zinc. The most non-resistant to the adverse effect of zinc are plant roots of variety Kutulukskaya.

Varieties Nargiz, Ulbinka-25 and Altai have the highest, Glubochanka, Omskaya-18, Zaulbinka, Lyazzat Zaulbinka and Kutulukskaya have an average, and Erythrospermum-606 and Samal have the lowest Wilkins coefficient or index of tolerance at a high concentration of cadmium (Table 1). Based on the results of the study of root growth in polluted by cadmium ions medium and on index of tolerance varieties Nargiz, Ulbinka-25 and Altai can be identified as genotypes with the most resistant towards the adverse effect of cadmium root system.

Altai variety has the highest, varieties Ulbinka-25 and Zaulbinka have an average, and Kutulukskaya and Erythrospermum-606 varieties have the lowest Wilkins coefficient at a high zinc concentration (table 2 ). Based on the results of the study of root growth in polluted by zinc ions medium and on index of tolerance genotypes Altai and Ulbinka-25 can be identified as the most resistant toward the adverse effect of zinc root system.

During the research testing of spring wheat contrasting by resistance genotypes we tested on permeability of cell membranes. Membrane permeability change is one of the symptoms of plants reaction to the external influence. It is known, that the exit of electrolytes is the membrane permeability function, which in its turn describes the damage extent [5]. Therefore, genotypes resistant to adverse environmental factors must have different physicochemical membrane characteristics.

Study on the cadmium ions influence on cell membrane permeability of surface organs of resistant Altai and sensitive Erythrospermum-606 wheat genotypes, showed that the permeability of cell 
membranes for electrolytes increase at a high cadmium (40 mg /l) concentration (table 3).

The leaf tissues cell membranes permeability of winter wheat variety Altai increased for $23 \%$ under the cadmium influence regarding control. Leaf cell membrane permeability of spring wheat variety Erythrospermum-606 increased for $75 \%$ under the cadmium influence (table 3 ).

It should be mentioned that cell membrane permeability for electrolytes of more resistant wheat variety Altai's changed less comparing to more sensitive genotype Erythrospermum-606.

Study on the influence of zinc ions on the cell membrane permeability of surface organs of resistant Altai and sensitive Erythrospermum-606 wheat genotypes, showed that cell membrane permeability for electrolytes increases at a high concentration of zinc (400 mg / 1) (table 4). Cell membranes permeability of leaf tissues of spring wheat variety Altai increased for $13 \%$ under the zinc influence regarding control. Leaf cell membrane permeability of winter wheat variety Erythrospermum-606 increased by $45 \%$ under the zinc influence relatively to control (table 4).

It should be mentioned that cell membrane permeability for electrolytes of resistant wheat variety Altai changed less comparing to more sensitive Erythrospermum-606, both under the cadmium and under zinc effect. The reason for strong inhibition of spring wheat Erythrospermum's-606 growth processes, as well as the relative stability of Altai varieties to the heavy metals toxic effect can be cell membrane's different ability to resist the stress, particularly the strong effect of heavy metals.

Membrane permeability change under stressful conditions proves structural restructure of membranes, which defines plants' potentially possible mechanisms to resist adverse environmental factors [6]. As a result of change of cell membrane permeability under influence of various factors, the intensive output of electrolytes from cells is happening. Intensity of secretion of electrolytes depends on varietal features.

\section{CONCLUSION}

As a result of a comprehensive study of zinc and cadmium effect on the growth of surface organs and sprout roots of different wheat genotypes, resistant and sensitive by growth parameters winter wheat genotypes were identified in the laboratory conditions.

Zaulbinka and Altai spring wheat varieties are the most resistant to zinc translocation into the surface organs in terms of the experiment, and Erythrospermum-606 is the most sensitive spring wheat variety. Altai spring wheat variety has shown the biggest root resistance towards the zinc effect.

Altai, Nargiz and Glubochanka spring wheat varieties can be considered the most resistant to cadmium translocation into the surface organs among the studied genotypes in terms of the experiment, and Erythrospermum-606 is the most sensitive spring wheat variety. Nargiz, Ulbinka-25, Altai and Glubochanka spring wheat varieties have shown the biggest root resistance towards the cadmium effect.

Altai spring wheat variety has demonstrated the biggest resistance to both zinc and cadmium translocation into the surface organs.

Membrane permeability of more resistant wheat variety was changing in less degree comparing to more sensitive wheat genotype, both under the cadmium and the zinc effect. This fact indicates that the overall resistance of plants may be due to their cell membrane resistance towards the stressor effect. 


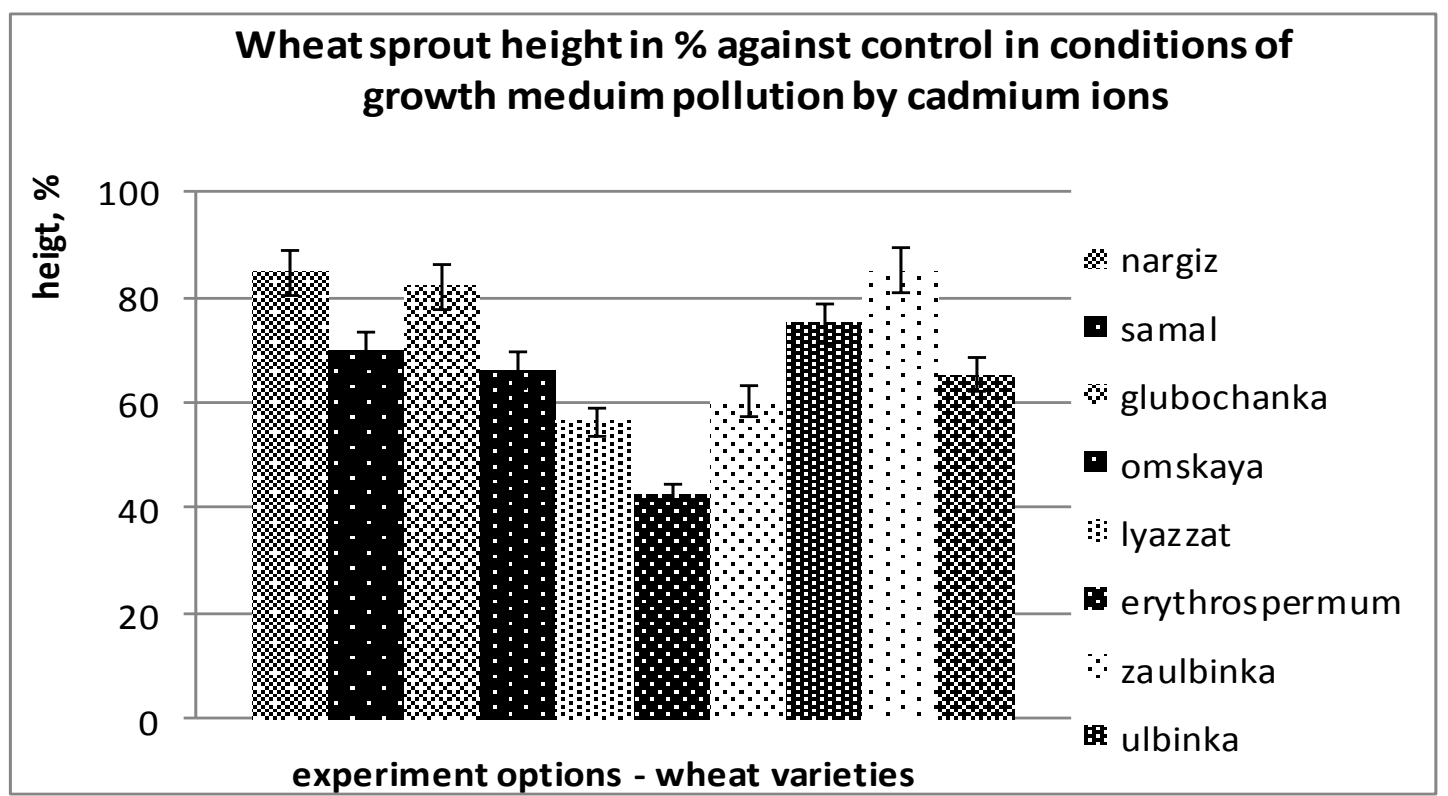

Figure 1: Influence of cadmium ions presence in growth medium on sprout growth of different wheat genotypes

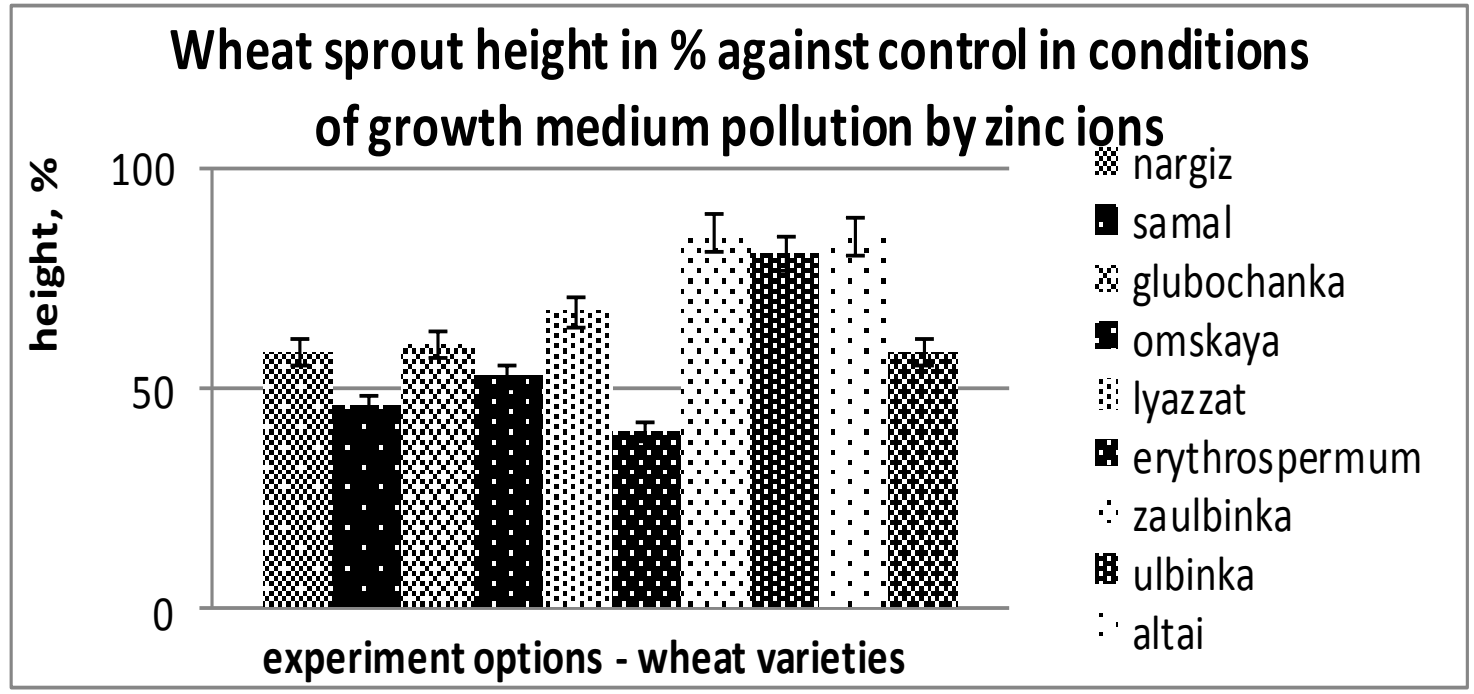

Figure 2: Influence of zinc ions presence in growth medium on sprout growth of different wheat genotypes 


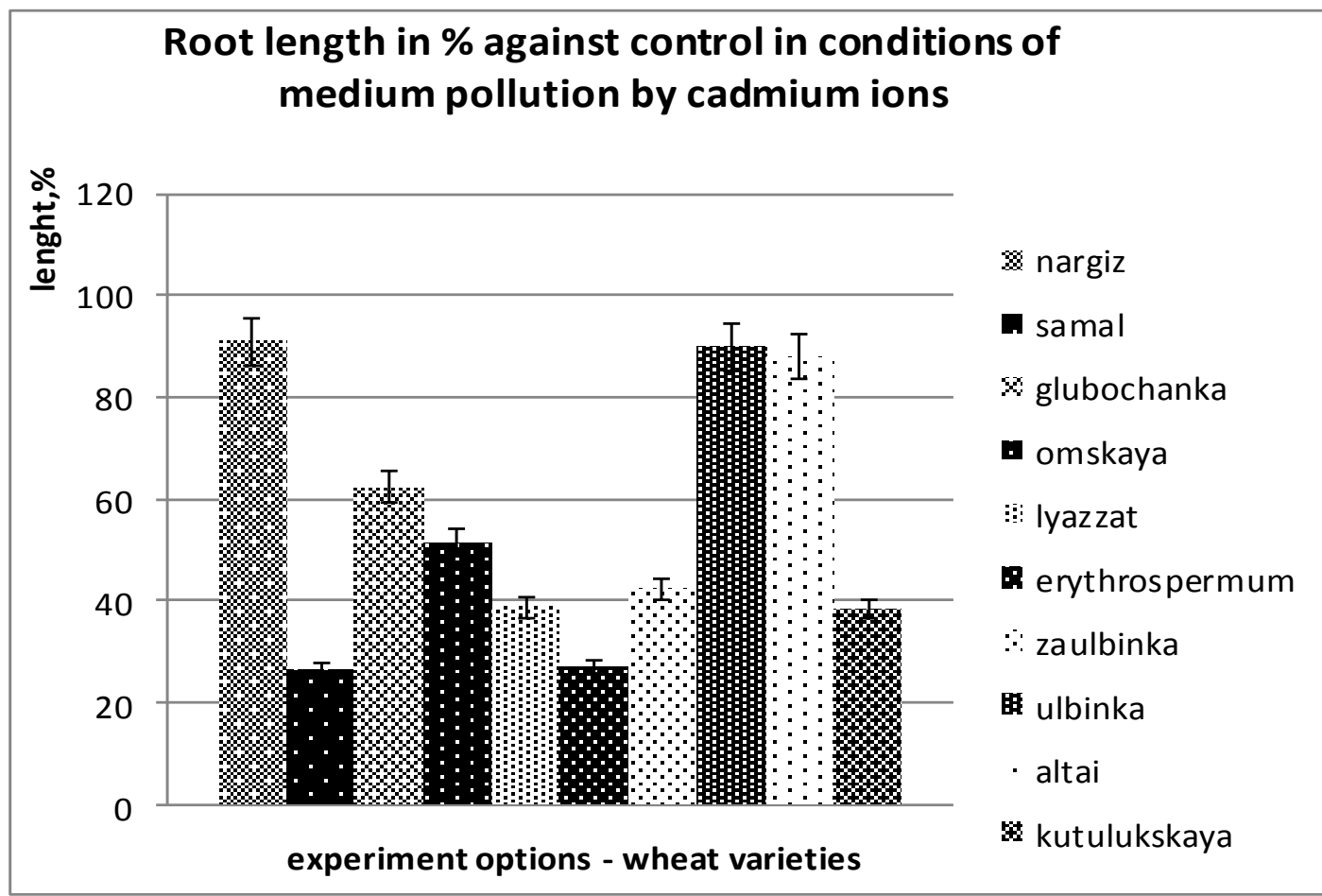

Figure 3: Influence of cadmium ions presence in growth medium on root growth of different wheat genotypes

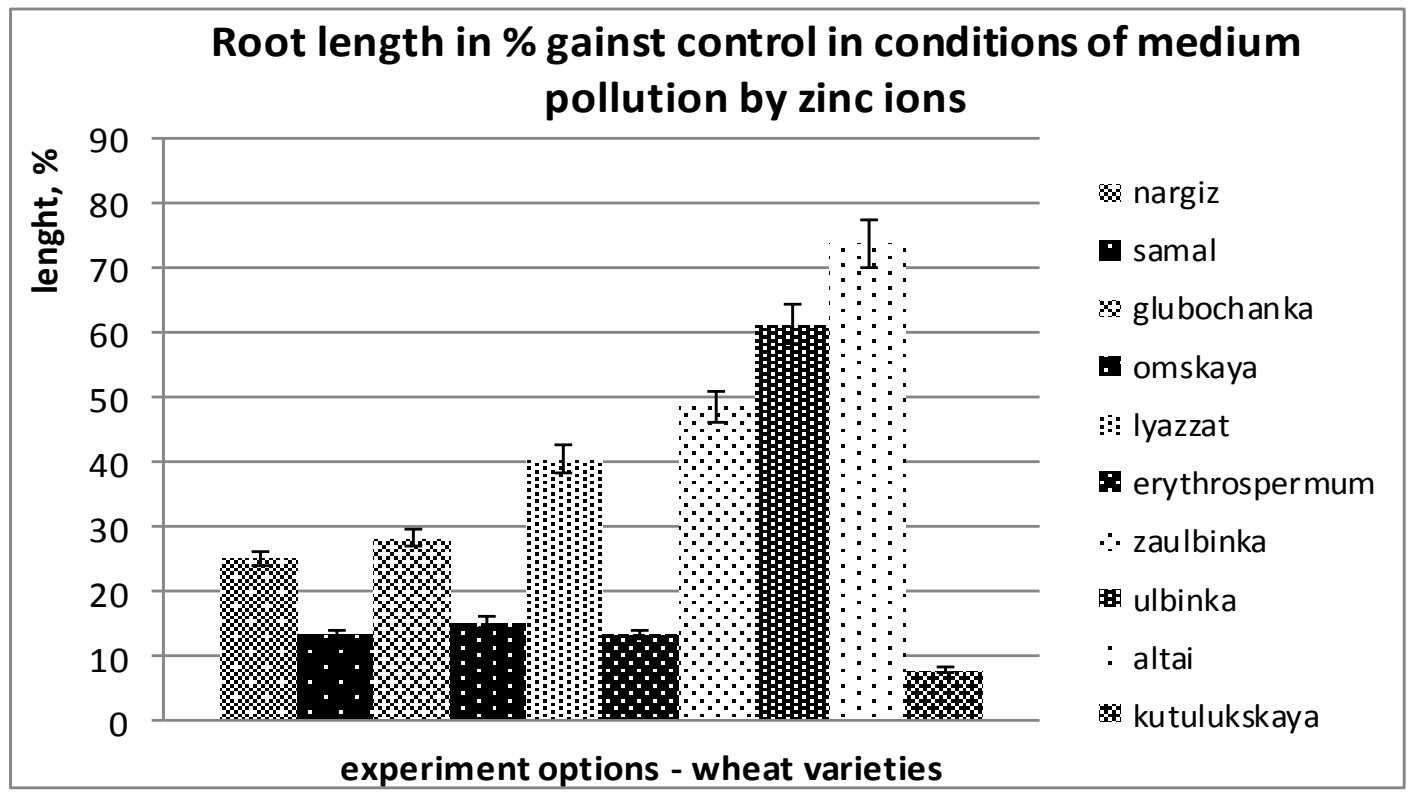

Figure 4: Influence of zinc ions presence in growth medium on root growth of different wheat genotypes 
Table 1: Wilkins Coefficient or tolerance index of wheat sprout roots in polluted by cadmium ions cultivation environment

\begin{tabular}{|c|c|c|c|c|c|c|c|c|c|c|}
\hline $\begin{array}{l}\text { Wheat } \\
\text { varieties }\end{array}$ & Nar-giz & Samal & $\begin{array}{l}\text { Glubochank } \\
\text { a }\end{array}$ & Omskaya-18 & Lyaz-zat & $\begin{array}{l}\text { Erythrosper } \\
\text { mum-606 }\end{array}$ & Zaul-binka & Ulbinka-25 & Altai & Kutulukskaya \\
\hline Ime, & 12,08 & 8,36 & 15,17 & 12,63 & 10,33 & 4,6 & 6,9 & 8,8 & 11,15 & 9,6 \\
\hline Ic & 13,29 & 31,46 & 24,36 & 24,60 & 26,70 & 16,9 & 16,3 & 9,8 & 12,7 & 25 \\
\hline It & 0,91 & 0,27 & 0,62 & 0,51 & 0,39 & 0,27 & 0,42 & 0,90 & 0,88 & 0,38 \\
\hline
\end{tabular}

Table 2: Wilkins Coefficient or tolerance index of wheat sprout roots in polluted by zinc ions cultivation environment.

\begin{tabular}{|c|c|c|c|c|c|c|c|c|c|c|}
\hline $\begin{array}{l}\text { Wheat } \\
\text { varieties }\end{array}$ & Nargiz & Samal & $\begin{array}{l}\text { Glubochank } \\
\text { a }\end{array}$ & Omskaya-18 & Lyazzat & $\begin{array}{l}\text { Erythrosper } \\
\text { mum-606 }\end{array}$ & Zaul-binka & Ulbinka-25 & Altai & $\begin{array}{l}\text { Kutulukska } \\
\text { ya }\end{array}$ \\
\hline $\mathrm{I}_{\mathrm{me}}$ & 3,32 & 4,17 & 6,87 & 3,72 & 10,79 & 2,2 & 7,9 & 6 & 9,4 & 1,9 \\
\hline $\mathrm{I}_{\mathrm{c}}$ & 13,29 & 31,46 & 24,36 & 24,60 & 26,70 & 16,9 & 16,3 & 9,8 & 12,7 & 25 \\
\hline $\mathrm{I}_{\mathrm{t}}$ & 0,25 & 0,13 & 0,28 & 0,15 & 0,40 & 0,13 & 0,48 & 0,61 & 0,74 & 0,08 \\
\hline
\end{tabular}


Table 3: Cadmium ions influence on the exit of electrolytes from leaf tissues of 10-days-old wheat sprouts.

\begin{tabular}{lcc}
\hline Options & $\%$ the exit of electrolytes & $\%$ against control \\
\hline Altai & & 100 \\
Control & $2,50 \pm 0,04$ & 123 \\
Cd $\quad 40 \mathrm{mg} / \mathrm{l}$ & $3,17 \pm 0,01$ & 100 \\
Erythrospermum-606 & & $3,12 \pm 0,02$ \\
Control & $5,52 \pm 0,01$ & 175 \\
Cd $\quad 40 \mathrm{mg} / \mathrm{l}$ & & \\
\hline
\end{tabular}

Table 4: Zinc ions influence on the exit of electrolytes from leaf tissues of 10-days-old wheat sprouts

\begin{tabular}{lll}
\hline Options & $\%$ the exit of electrolytes & $\%$ against control \\
\hline Altai & & 100 \\
Control & $2,50 \pm 0,04$ & 113 \\
$\mathrm{Zn} 400 \mathrm{mg} / \mathrm{l}$ & $2,84 \pm 0,05$ & 100 \\
Erythrospermum-606 & & 145 \\
Control & $3,12 \pm 0,02$ & 145 \\
$\mathrm{Zn} \quad 400 \mathrm{mg} / \mathrm{l}$ & $4,63 \pm 0,015$ & \\
\hline
\end{tabular}




\section{REFERENCES}

Alybaeva R.A. (2007) Evaluation of the ecological status of soils in Ust-Kamenogorsk, Bulletin of the KNU, environmental Series 2 (21), 40-44.

Wu Feibo, Zhang Guoping (2002) Genotypic variation in kernel heavy metal concentrations in barley and affected by soil factors, Journal Plant Nutrition. 25 (6) 1163-1173.

Koval S.F. (1974) Investigation of the cell membranes properties and the resistance of plants by elution of electrolytes. News of the Sib. Branch of the Academy of Sciences of the USSR. Series of Biological Sciences, 15 (3), 161-167.
Dospekhov B.A. (1985) Methodology of field experience Moscow: Agro-industrial Publishing.

Stevavic B., Sinzar I., Glisic O. (1998) Electrolyte leakage differences between poikilohydrous and homoiohydrous species of Gesneriaceae. Biologia Plantarum. 2 (40), 229303.

Altergot V.F. (1976) Principles of physiological studies and problems of crop production in Siberia. In the book: Physiology of plant resistance to continental climate. Novosibirsk 4-14. 